H. LI, ${ }^{1}$ Y. M. ZUO,${ }^{1}$ Y. H. LEI, ${ }^{1}$ R. J. XU,${ }^{1}$ and Y. WANG ${ }^{1}$

\title{
MODELING OF DIABETES MELLITUS-RELATED DEPRESSION
}

\author{
Received December 10, 2012
}

Research on the mechanisms of diabetes-related depression is limited by the lack of sufficiently adequate animal models. Among 80 rats, we formed four groups: (i) normal (N, control), (ii) with streptozotocin (STZ)-induced diabetes mellitus (group Dm), (iii) with a depression model induced by various mild but long-lasting repetitive stressogenic stimulations applied each day during 4 weeks (group D), and (iv) diabetic rats subjected to the combined action of stressogenic influences (group DmD). The latter group (35 animals) was divided into two subgroups, DmD1 subjected to the above chronic stressogenic stimulations, and DmD2 in which diabetic rats were during the above period (4 weeks) kept in isolation. Rats of groups Dm, D, and DmD manifested clear behavioral symptoms of depression. These symptoms were relatively mild in group Dm and much more intense in group DmD. The body mass of rats noticeably decreased in the Dm and D groups and dramatically dropped in the $\mathrm{DmD}$ group. In this group, diabetes-related changes in the levels of blood glucose, insulin, and hemoglobin $\mathrm{A} 1 \mathrm{C}$ were the greatest. The same relates to the behavioral indices demonstrated by rats in the open field test. The contents of norepinephrine, 5-hydroxytryptamine, and dopamine in the thalamus of rats of groups Dm, D, and DmD were lower than in the norm, and these shifts where most dramatic in the DmD group. The levels of ACTH and cortisol increased in the experimental groups; again, shifts were the greatest in the $\mathrm{DmD}$ group. RT PCR and Western blotting showed that the level of NPY protein in the hypothalamus was lower in groups $\mathrm{Dm}, \mathrm{D}$, and $\mathrm{DmD}$ than that in the norm. Thus, chronic unpredictable stressogenic stimulation or behavioral isolation of diabetic rats significantly aggravates manifestations of depression and stably provides the formation of an adequate animal model of diabetes-related depression. Keeping animals in isolation (subgroup DmD2) is more suitable for empirical studies because of a lower mortality.

Keywords: diabetes mellitus, depression, stress, animal model, rats.

\section{INTRODUCTION}

Diabetes mellitus is a widespread endocrinal systemic metabolic disease. Unhealthy psychological state, character defects, and emotional disorders are usual diabetes-related pathopsychological features. Diabetes-induced depression is a chronic disease; it not only disturbs curative effects of therapy and worsens the prognosis but also significantly decreases the quality of life of patients suffering from diabetes. The suicide rate in diabetes-related depression is higher than in other populations [1-3]. Problems induced by diabetes mellitus are attracting more and more attention. Therefore, the psychological treatment plays an important role in combined-modality therapy

${ }^{1}$ Long Hua Hospital, Shanghai University of Traditional Chinese Medicine, Shanghai, China

Correspondence should be addressed to

Hong Li (e-mail: hongli-sutcm@hotmail.com) of diabetes.

So far, research on diabetes-related depression remains insufficient, and there is a deficiency in adequate animal models of this type of depression. The aim of our study was to build an animal model of diabetes-related depression that could be sufficiently analogous with respect to clinical symptoms of such depression in humans and suitable for research.

\section{METHODS}

Experimental groups. In our experiments, 80 Sprague-Dawely (SD) male rats with body mass 180-190 g were used. Rats were housed under standard conditions of ligh/darkness $12 / 12 \mathrm{~h}$ (with light onset at 8:00 a.m.), temperature $21-23^{\circ} \mathrm{C}$, and humidity 40-50\%; food and water were available ad libitum. The rats were randomly assigned to one of four distinct 
groups: 15 rats for the normal $(\mathrm{N})$ group, 15 animals for the diabetes mellitus (Dm) group, which received STZ, 15 rats for the depression (D) group, and 35 rats for the diabetes-related depression (DmD) group. The latter group was separated into two subgroups. In the DmD1 subgroup, 15 rats were kept alone; while 20 rats of the in $\mathrm{DmD} 2$ subgroup received chronic unpredictable stress stimulation.

Diabetes mellitus model. The Dm and DmD groups were both subjected to i.p. injections of $0.5 \mathrm{ml} \mathrm{CFA}$, and STZ solution $(30 \mathrm{mg} / \mathrm{kg})$ was i.p. injected on the next day. The injection was given once a week, and the cycle lasted three weeks. The body mass and blood glucose were measured after the course of injections. The diabetes mellitus model was considered to be built successfully when the concentration of blood glucose exceeded $16 \mathrm{mM}$.

Depression model. The D-group rats were subjected in a randomized order to seven distinct chronic unpredictable stresses within a week. One stress was given each day, and the same stress could not be administrated consecutively. The whole course lasted for 4 weeks. The methods of stimulations included lighting all night, tilting the cage for $17 \mathrm{~h}$, water deprivation for $16 \mathrm{~h}$ followed by empty bottle stimulation for $1 \mathrm{~h}$, soft constraining of the animal for $3 \mathrm{~h}$, fasting for $24 \mathrm{~h}$, breeding in the group for $17 \mathrm{~h}$, and dabbling the cage for $17 \mathrm{~h}$. The depression model was considered to be built successfully when animals displayed a decrease in body mass, deficiency of action, novelty-seeking and aggressive behavior, and significant decrease in the intensity of grooming and food consumption.

Diabetes+depression model. In the $\mathrm{DmD}$ group, rats with $\mathrm{STZ}$-induced diabetes were subjected to two types of the above-mentioned stressogenic influences (subgroups DmD1 and DmD2). The diabetes + depression model was considered to be built successively when the rats simultaneously displayed changes analogous to those in the above Dm and D groups.

When the models had been built, the mental status, state of the motor activity, fur status, body mass, and mortality of rats were monitored. The blood glucose level was routinely measured by a glucometer, and the glycosylated hemoglobin (HbA1C) level was measured by a respective analyzer; the procedures were mainly in accordance with the user's guide but with some modifications. Blood samples were taken from the tail vein.

Behavior Testing. A standard open field test was used; it was carried out in a sound-free and temperatureand light-controlled room at 7:30 a.m. until 12:00. The open field chamber $(76 \times 76 \times 42 \mathrm{~cm})$ was made of an opaque material with the floor divided into 25 equal squares. The observation time interval was 5 min long. Scores of horizontal movements (locomotor activity), numbers of rearing (vertical activity), time spent in the central square, number of cleaning motions (grooming), and number of fecal boluses within the above interval were counted. The apparatus was cleaned between the trails.

ELISA test. Blood samples were taken at the onset of sacrifice and centrifuged for $10 \mathrm{~min}$ at $3000 \mathrm{~min}^{-1}$. Plasma was then collected and frozen at $-80^{\circ} \mathrm{C}$ until RIA and ELISA measurements. Insulin (Ins) and ACTH levels were measured with LINCO (USA) and Beijing North Institute of Biological Technology (China) kits, respectively, according to the manufacturer's specifications. The blood samples for ELISA were allowed to stand for $2 \mathrm{~h}$ at room temperature and centrifuged at $1000 \mathrm{~g}$ for $20 \mathrm{~min}$. The supernatant was taken for the ELISA test. The cortisol (Cort) level was quantified by an ELISA kit (R and D Systems, USA).

HPLC test. Rats were sacrificed $24 \mathrm{~h}$ after the experiments. The thalamus was placed rapidly on ice, weighed, and stored at $-80^{\circ} \mathrm{C}$. Reversed-phase HPLC with electrochemical detection was used to measure the concentrations of norepinephrine (NE), 5-hydroxytryptamine (5-HT), and dopamine (DA).

Real-time PCR. The NPY mRNA level was measured in the hypothalamus tissue by real-time quantitative PCR. Samples of total-tissue RNA $(2.5 \mu \mathrm{g})$ in each group were extracted by the Triazole method. The random primers and M-MLV were used for reverse transcription. The NPY specific primers for real-time PCR were designed by Primer 5.0. $\beta$-Actin mRNA was used as an internal standard. The real-time PCR was performed on a real-time fluorescent quantitation PCR instrument (Mastercycler ep realplex, Germany). The NPY primers used in our study were the following: Forward: 5'-GTGTGTTTGGGCATTCTGG-3' and Reverse: 5'-GGCATTTTCTGTGCTTTCTCT-3'. The primer for $\beta$-actin were Forward: AACCCTAAGGCCAACAGTGAAAAG and Reverse: TCATGAGGTAGTCTGTGAGGT.

Western blotting. Tissue samples from the hypothalamus were taken and homogenized in a lysis buffer $(5-10 \mu \mathrm{l} / \mathrm{mg}$ tissue) containing a mixture of protease inhibitors (Roche, Switzerland). After incubation on ice, the samples were centrifuged, and the supernatants were used for Western blotting. A BCA method was used for 
measuring the concentration and content of protein in the samples. Equal amounts of total protein $(40-60 \mu \mathrm{g})$ or nuclear protein $(10-20 \mu \mathrm{g})$ were loaded and separated in SDS-PAGE gel. The resolved proteins were transferred onto polyvinylidene difluoride (PVDF) membranes (Amersham Bioscience, UK). The PVDF membranes were blocked in $10 \%$ nonfat milk for $30 \mathrm{~min}$ at room temperature and incubated with rabbit antimouse NPY primary antibody (1: 500, Santa Cruz, USA) overnight at $4{ }^{\circ} \mathrm{C}$. Then the membranes were incubated with HRP goat antirabbit secondary antibody (1: 2000, Santa Cruz, USA) for $1 \mathrm{~h}$ at the same temperature. The signals were visualized using enhanced chemiluminescence (ECL, Pierce, USA). The blots were scanned and analyzed with a gel-imaging analysis system (Bio-Rad, USA). As the internal control, $\beta$-actin was used.

Statistical analyses. The numerical data in this study were analyzed with SPSS17.0 software. The enumeration data were analyzed using the $\chi^{2}$ test. In the case of normal distribution of the values, the Student's $t$-test was used for estimation of intergroup differences; in other cases, the rank sum test was applied. For all experiments, the differences were considered significant at $P<0.05$.
A
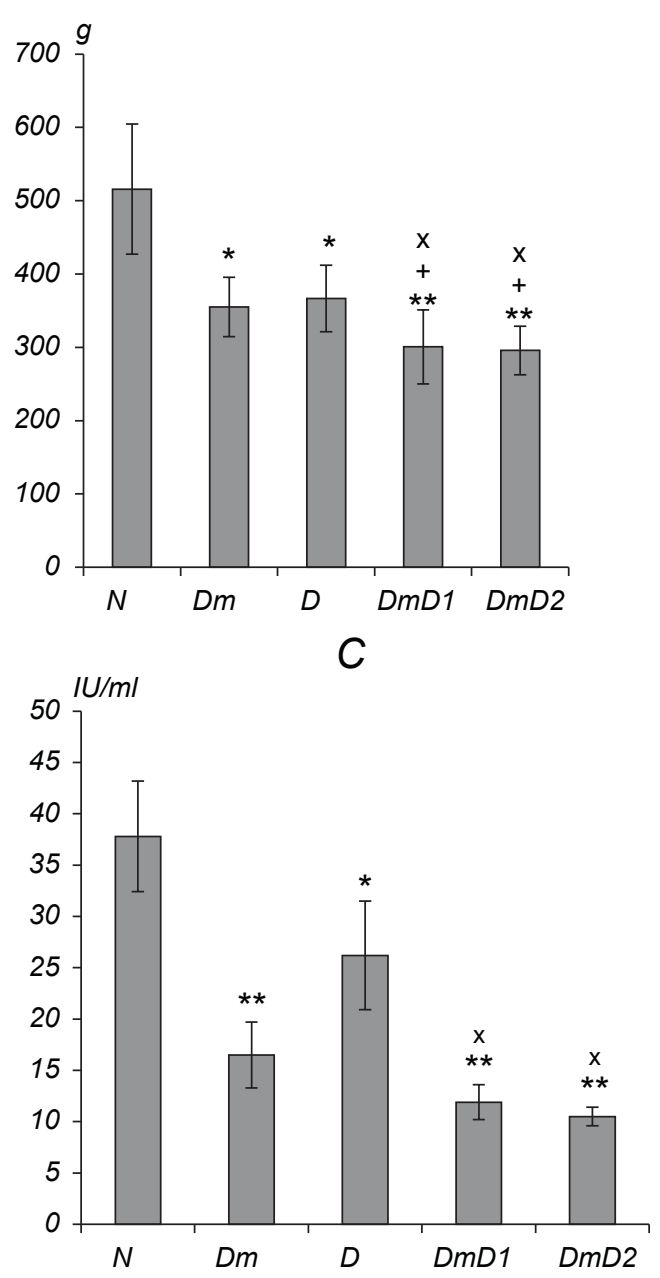

B
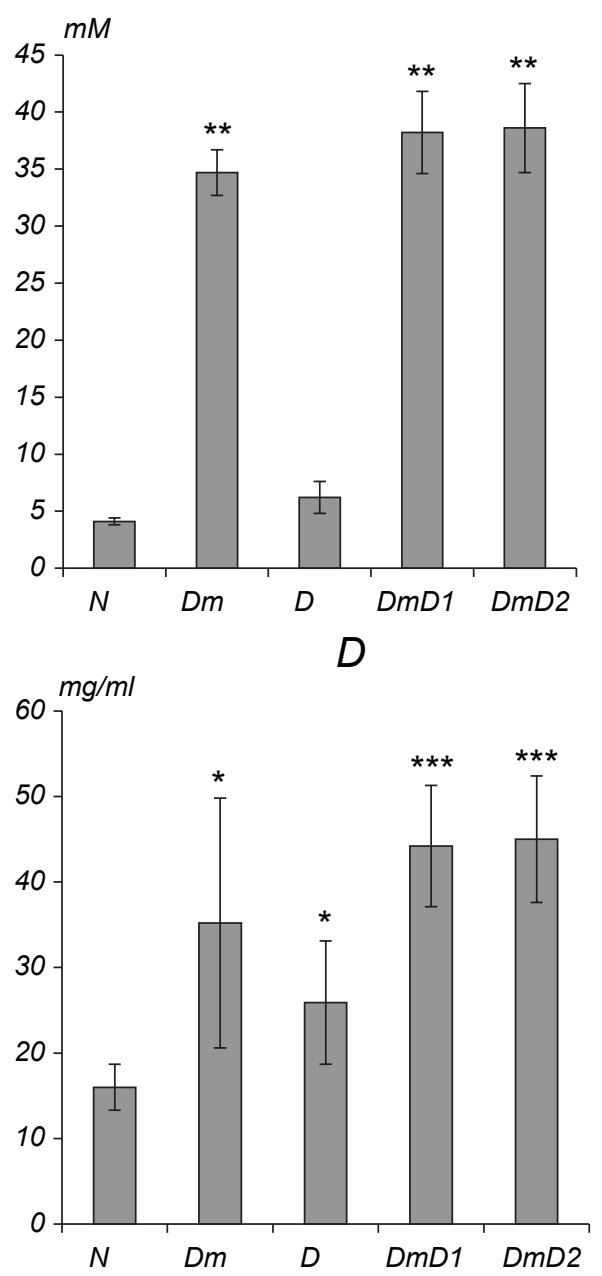

F i g. 1. Mean values of the body mass (A) and levels of blood glucose, BG (B), insulin, Ins (C), and hemoglobin A1C, HbA1C (D) in the examined groups. $\mathrm{N}$ is normal (control); Dm, animals with experimental diabetes mellitus; $\mathrm{D}$, rats with stress-induced depression, and $\mathrm{DmD} 1$ and DmD2 are animals of two subgroups of the diabetes + depression group. $* P<0,05$ and $* * P<0,01$, as compared with group $\mathrm{N}$, $+P<0,05$ and $++P<0,01$, as compared with group Dm, and $\times P<0,05$ and $\times \times P<0,01$, as compared with group $\mathrm{D}$.

Р и с. 1. Середні значення маси тіла $(A)$ та рівнів глюкози $(B)$, інсуліну $(C)$ та гемоглобіну А1C $(D)$ у крові щурів досліджених груп. 


\section{RESULTS}

State of the animals in the diabetes-related depression model. We compared the status of mental abilities, motor behavior, appearance, appetite, and mortality between all model groups. Rats of all groups were observed for 12 weeks following the model building. When the models were formed successfully, rats of the Dm, D, and DmD groups displayed an unhealthy mental status, torpid actions, and slow reactions to adequate sensory stimuli. Both the glossiness of fur and body mass decreased significantly. Food consumption was reduced in the D group. Rats of the Dm and DmD groups demonstrated polydipsia, polyphagia, and polyuria. Thus, there were some common symptoms in the three groups, but the levels of their manifestation were dissimilar (see below). The mortality in the groups was different. After the above-mentioned period of observation, 10 of 20 rats were alive in the DmD2 subgroup; in the DmD1 and Dm groups this index was $12 / 15$ and $13 / 15$, respectively; there were no cases of death in the $\mathrm{D}$ and $\mathrm{N}$ groups.
The body mass and levels of blood glucose (BG), Ins, and $\mathrm{HbA1C}$ in the experimental groups. The mean body mass and levels of BG, Ins, and $\mathrm{HbA} 1 \mathrm{C}$ in the three model groups differed from the respective indices in the $\mathrm{N}$ group. Compared to the latter, the body mass and Ins level in the model groups decreased significantly $(P<0.01)$. At the same time, the BG level (except group D) and HbA1C increased in the model groups $(P<0.05$ or $P<0.01)$. We found that the means of the body mass, BG, Ins, and HbA1C in the DmD1 and DmD2 subgroups were different from those in the $\mathrm{Dm}$ and D groups. The levels of BG and $\mathrm{HbA1C}$ in subgroups DmD1 and DmD2 were higher than those in the Dm and D group, while there was body mass loss and lower Ins, as compared with the respective values in the Dm and D groups $(P<0.05$ or $P<0.01)$. Meanwhile, the BG, $\mathrm{HbA} 1 \mathrm{C}$, and Ins in the Dm group differed from the corresponding values in the D group; the body mass was an exception (Fig. 1).

The state of behavioral activity in experimental groups. After all the models were formed successfully, the intensities of horizontal and vertical movements and the number of cleaning behavior episodes were

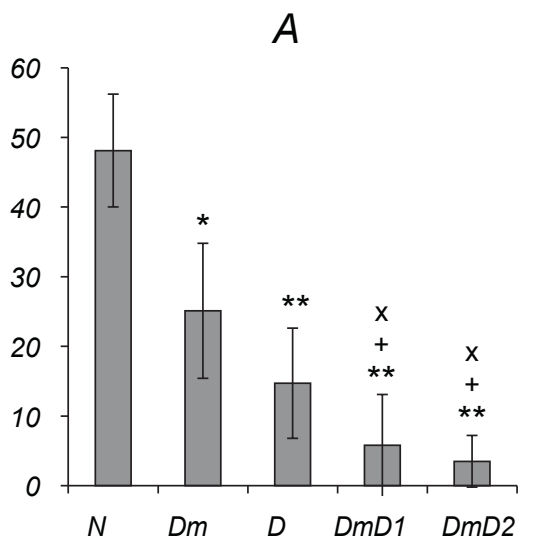

$D$

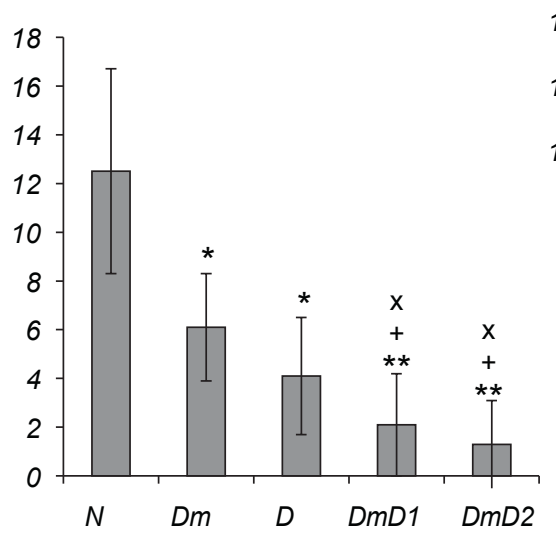

$B$

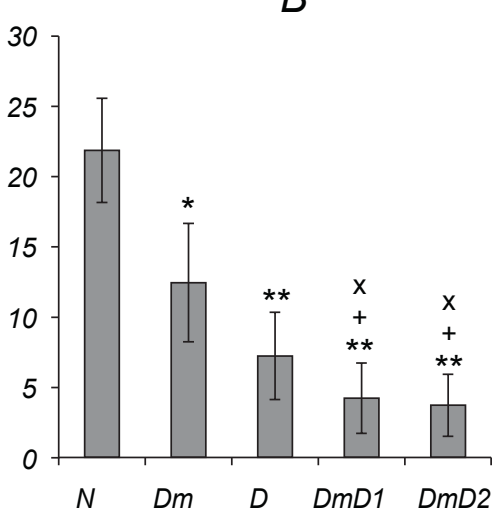

E

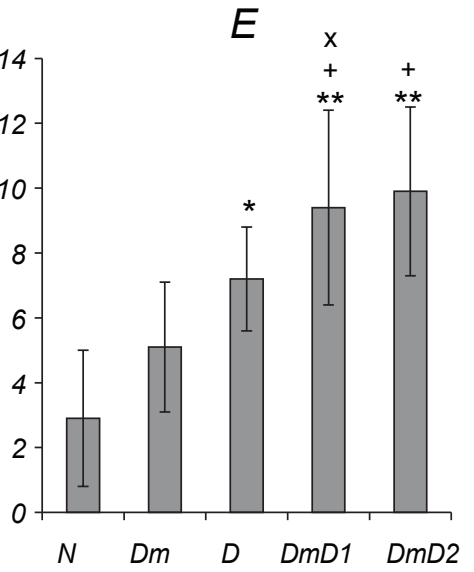

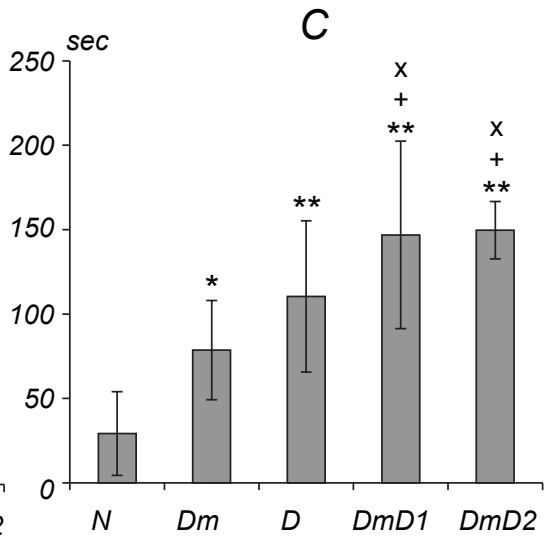

F i g. 2. Mean values of the behavioral indices demonstrated in the open field test by animals of the examined groups. A) Horizontal movements; B) vertical movements; C) time spent in the central square; D) number of grooming acts, and E) number of defecations within the observation period. Other designations are similar to those in Fig. 1.

Р и с. 2. Середні значення поведінкових показників, продемонстрованих у тесті відкритого поля тваринами досліджених груп. 

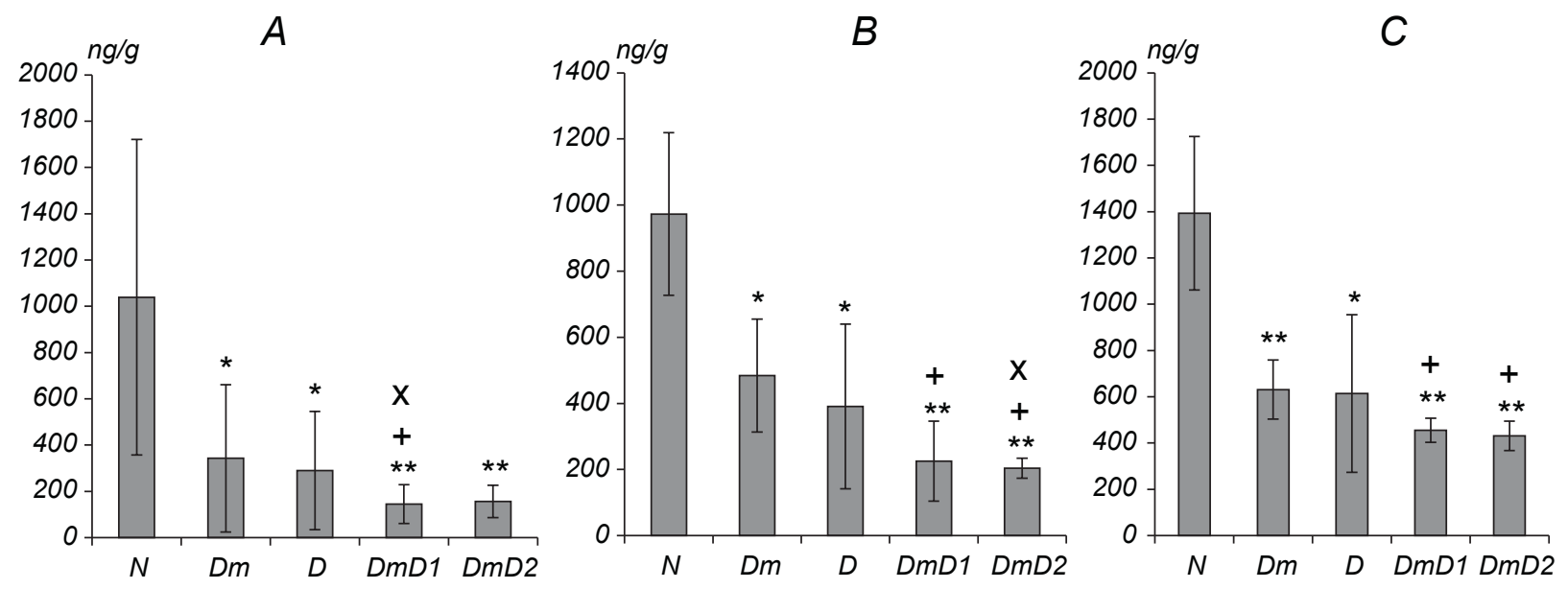

F i g. 3. Contents of monoamine transmitters in the thalamus of animals of the studied groups. A-C) Levels of norepinephrine (A, ng/g), dopamine $(\mathrm{B}, \mathrm{ng} / \mathrm{g})$, and 5-hydroxytryptamine $(\mathrm{C}, \mathrm{ng} / \mathrm{g})$. Other designations are similar to those in Fig. 1.

Р и с. 3. Вміст трансмітерів-моноамінів у таламусі тварин досліджених груп.
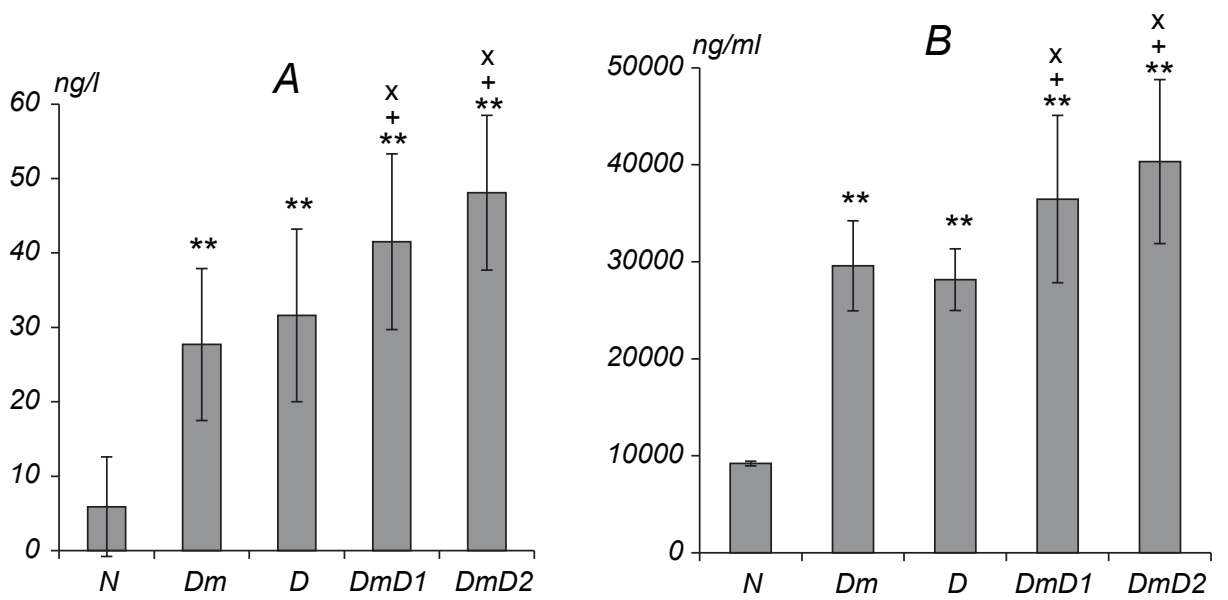

F i g. 4. Concentrations of $\mathrm{ACTH}$ (A, ng/ liter) and cortisol, Cort $(\mathrm{B}, \mathrm{pg} / \mathrm{ml})$ in the examined groups. Other designations are similar to those in Fig. 1.

P и с. 4. Концентрації АКТГ (A) та кортизолу $(B)$ у тварин досліджених груп.

reduced compared with the $\mathrm{N}$ group, while the time spent in the central square and number of defecations increased $(P<0.01)$. Horizontal and vertical motor activities and number of grooming episodes in the DmD1 and DmD2 subgroups were significantly smaller than those in the Dm and D groups $(P<0.05$ or $P<0.01)$. However, the time in the central square and number of defecations were greater than those in the latter groups. We also found that there was a marked difference in these five parameters between the Dm and D groups. Compared with the Dm group, the numbers of horizontal and vertical movements and cleaning motions were smaller (down-regulated) in the D group, but the time in the central grid and number of defecations increased (up-regulated). There were no statistically significant difference between the DmD1 and DmD2 subgroups (Fig. 2).
Contents of monoamine transmitters in the thalamus of rats of experimental groups. HPLCmeasurements of the contents of DA, 5-HT, and NE using in the thalamus of animals of different groups showed that the contents of these transmitters in the model groups were reduced significantly compared with the indices in normal rats $(P<0.05$ or $P<0.01$; $)$. The contents of NE, DA and 5-HT in the DmD1 and DmD2 subgroups were lower than those in the Dm and D groups. There was no significant difference between the DmD1 and DmD2 subgroups (Fig 3).

State of the neuroendocrine axis in the experimental groups. We also tested the state of the hypothalamo-pituitary-adrenal axis in the model groups. Compared with the normal group, the contents of ACTH and Cort in the three model groups were higher $(P<0.01)$; and the contents of these 

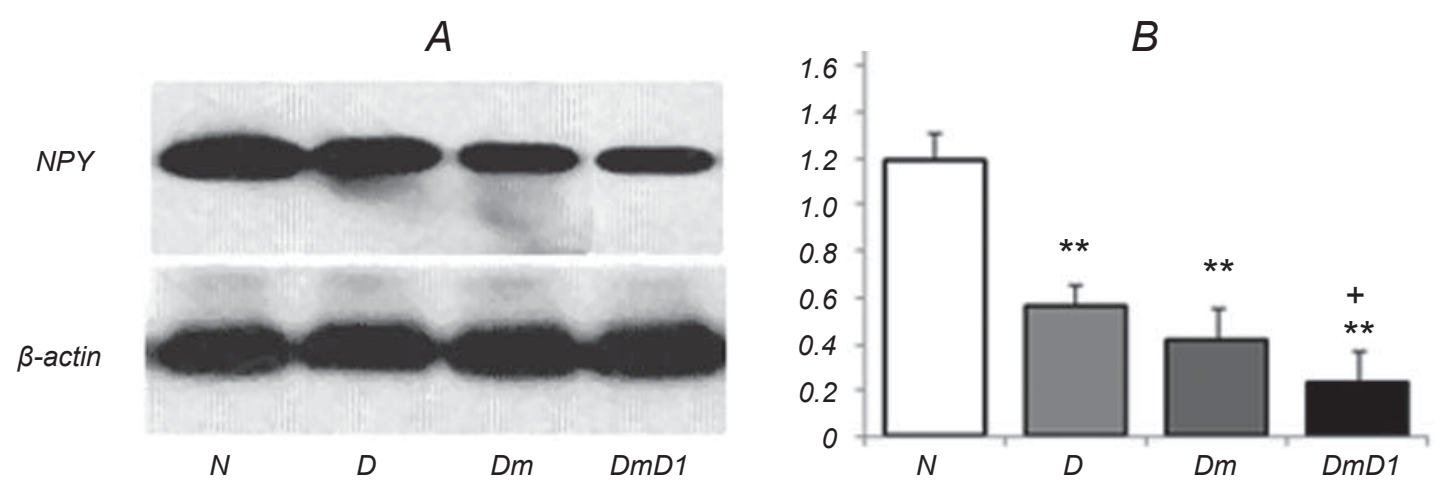

F i g 5. Expression of NPY protein in the hypothalamus of rats of the exthamined groups. A) Results of Western blotting; B) diagram of the relative level of NPI protein, arbitrary units. Other designations are similar to those in Fig. 1.

Р и с. 5. Експресія протеїну NPY в гіпоталамусі тварин досліджених груп.

hormones in the Dm and D groups were different from the respective values in the two diabetes-depression subgroups (DmD1 and DmD2). The contents of ACTH and Cort in both latter subgroups were considerably higher than those in the Dm and D groups. No statistical difference was found between the DmD1 and DmD2 subgroups (Fig 4).

Reduction of the NPY mRNA and protein contents in the hypothalamus of the diabetesdepression group. Using real-time PCR and Western blotting, we estimated the NPY mRNA and protein levels in the diabetes-associated depression model. The RT PCR results showed that the levels of NPY mRNA in the D group and DmD1 subgroup were lower than that in the normal group $(P<0.01$; Table 6$)$. The respective level in the DmD1 subgroup was lower than those in the Dm and D groups $(P<0.01)$. Meanwhile, the Western blotting results indicated that the levels of NPY protein in the Dm, D, and DmD1 groups were lower than the respective value in the normal group $(P<0.05$; Fig 5).

\section{DISCUSSION}

Diabetic patients manifest a number of pathopsychological shifts, such as an unhealthy general psychological state [4], character defection, and emotional disorders [1-3]. Successful building of a sufficiently adequate animal model of diabetesrelated depression is very important for the research of depression induced by diabetes mellitus in humans.

We used two approaches to form the diabetic depression animal model. The first method was keeping and feeding rats alone after STZ induction of diabetes mellitus. In the second mode, the rats were exposed to chronic unpredictable mild stress induced by various everyday randomized stress-inducing sessions. Our results showed that both diabetes depression subgroups demonstrated clearly manifested unhealthy behavior, torpid responses, retarded actions, and also reduction of furry glossiness and decrease in food and water consumption. All these phenomena conform to the main symptoms of endogenous depression and indicate that our diabetes+depression model was built effectively.

Lustman et al. suggested that depression additionally suppress secretion of islet cell, reduces glycometabolism, and promotes increase in the blood glucose level $[5,6]$. Our results also indicated that the levels of glucose and glycosylated hemoglobin in the diabetes depression subgroups were higher than those in the "pure" diabetes group, and the Ins level in the above two subgroups was noticeably lower than that in the latter group. These results suggest that there is a close relationship between generation of diabetesrelated depression and elevated blood glucose level.

Until now, it is acknowledged that a functional deficiency in 5-HT is the main biochemical change under conditions of depression [7,8]. The diabetic animal models manifested a similar feature [9]. Our studies show that the levels of 5-HT in the thalamus in $\mathrm{Dm}, \mathrm{D}$, and $\mathrm{DmD}$ animals were significantly lower than that in the normal group. In the two diabetic depression subgroups, the reduction of 5-HT was most considerable. Our results confirm that diabetes mellitus and depression are correlated and potentiate the dysfunction resulting in suppression of the 5-HT system.

In some studies, it was found that the $\mathrm{NE}$ concentration is changed in both depression and diabetes models $[7,10,11]$. Paschos et al. reported 
that derepression of $\mathrm{NE}$ is up-regulated in the peripheral nervous system, and the NE concentration is reduced in the hippocampus [12]. Ferraro et al. found that the concentration of NE increased in the blood plasma of patients with type I diabetes mellitus $[13,14]$. Nonetheless, data on the concentration of $\mathrm{NE}$ in diabetes depression are limited. In our study, we revealed that the level of NE in the thalamus of animals of all three model groups was significantly lower compared with the normal group. In the two diabetes depression subgroups (the entire DmD group), the shifts were the greatest.

Many studies have demonstrated that the synthesis, delivery, re-uptake, and metabolism of DA are abnormal in diabetes mellitus and also in depression [15]. In the brain of depressive rats, the content of DA was found to be remarkably reduced [10]. On the other hand, it was reported that the content of DA in the rat brain increased significantly on the 8 th week of type II diabetes. In other works, it was suggested that the DA content did not change in the cerebral cortex of diabetic rats. In our study, we found that the content of DA in the thalamus of model groups was lower than that in the normal group. These changes in the DmD group (both subgroups) were most significant. Disagreements between the above data may be due to differences between rat strains and to different formulations of the long-term experimental cycle. The absence of an effective treatment for diabetic rats in our experiments could intensify the reduction of the DA level in the brain of diabetic depressive rats.

It is generally recognized that the hypothalamopituitary-adrenal axis (HPAA) not only plays an important role in the development of depression and diabetes but is also closely related to stress [12, 16]. The levels of ACTH and Cort, two important hormones in this axis, are up-regulated in chronic stress $[12,17]$. After the antidepressant treatment, the concentrations of these hormones are down-regulated. A corresponding situation was also found in diabetic patients without depression. However, little is known on the concentration of ACTH and Cort in the plasma of diabetics with depression. Our research showed that the up-regulated concentrations of ACTH and Cort in both subgroups of the $\mathrm{DmD}$ group were more significant than those in the Dm and D groups; in other words, a combination of diabetes with depressioninducing influences promotes pathological shifts in the HPA.

It was reported that expression of NPY is downregulated in a gentle-depression model and in patients with depression [18]. As was also mentioned, the level of NPY mRNA and the respective protein is higher in the hypothalamus of diabetic rats [19]. Our study demonstrated that the level of NPY mRNA and protein is down-regulated in the hypothalamus of animals of the three model groups compared with that in the normal group, and shifts in the DmD group were most significant. Our results for the Dm group are not consistent with the previous reports. We think that such a discrepancy may be related to the fact that the diabetic rats did not obtain effective treatment and the higher blood glucose was not relieved in the long-term experiment. All these factors increased the intensity of depression and led to the reduction of NPY mRNA and protein in the hypothalamus of experimental animals.

In general, our results demonstrated that a combination of STZ-induced diabetes and chronic moderate unpredictable repetitive stress stimulation or behavioral isolation of the rats can stably lead to the formation of an animal model diabetes-related depression. The depressed state in this model can be maintained for a long time. Therefore, both the abovementioned two modes of combined action have allowed us to build an adequate animal model of diabetesassociated depression. The DmD2 subgroup, where rats were kept in isolation, appears more suitable for empirical studies because of the lower mortality of the animals.

All experiments were conducted with the approval of the local Animal Care Ethics committee of the Shanghai University of traditional Chinese medicine.

The authors of the report, H. Li, Y. M. Zuo, Y. H. Lei, R. J. Xu, and Y. Wang, have no conflict of interest.

Acknowledgment. This work was supported by the National Natural Science Found of China (NSFC Grants 81072793) and Shanghai Schoolboard Scientific Research Key Project Founding (SSSRF Grants 11ZZ114).

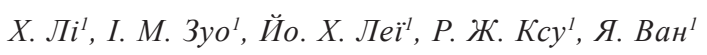

МОДЕЛЮВАННЯ ДЕПРЕСІЇ,, ПОВ'ЯЗАНОЇ З ЦУКРОВИМ ДІАБЕТОМ

${ }^{1}$ Лікарня Лонг Хуа при Шанхайському університеті традиційної китайської медицини (Китай)

P е 3 ю м е

Ефективність досліджень механізмів депресії, пов'язаної 3 цукровим діабетом, обмежується недостатністю адекватних 
експериментальних моделей. Із 80 щурів ми сформували чотири групи: нормальну (N, контроль), групу Dm iз стрептозотоциніндукованим експериментальним діабетом, групу D 3 ознаками депресії, індукованої помірними за силою, але тривалими повторюваними різноманітними стресогенними стимуляціями, що реалізувалися в рандомізованому порядку щоденно протягом чотирьох тижнів, а також групу DmD, котра складалася зі щурів із діабетом, підданих хронічним стресогенним впливам. Остання група (35 тварин) була розділена на дві підгрупи: DmD1, піддану вказаним стресогенним стимуляціям, та $\mathrm{DmD} 2$, в якій щури з діабетом утримувалися в ізоляції протягом аналогічного періоду (чотири тижні). У щурів груп Dm, D i DmD проявлялися виражені поведінкові симптоми депресії. Ці симптоми були порівняно слабкими в групі Dm i найбільш інтенсивними в групі $\mathrm{DmD}$. Маса тіла тварин помітно зменшувалася порівняно 3 нормою в групах Dm i D та різко падала в групі DmD. У цій групі пов'язані з діабетом зміни рівнів глюкози в крові, інсуліну та гемоглобіну А1C були найбільшими. Те ж саме стосувалося поведінкових індексів, що визначалися в щурів у тесті відкритого поля. Рівні норадреналіну, серотоніну та дофаміну в таламусі щурів груп Dm, D i DmD були нижчими за норму; ці зрушення виявилися найбільш драматичними в групі DmD. Рівні AKTГ і кортизола в експериментальних групах зростали; ці зміни також були найбільш значними в групі DmD. Виміри з використанням полімеразної ланцюгової реакції та Вестерн блоттингу вказували на зниження рівня протеїну NPY в групах Dm, D i DmD. Таким чином, помірна за силою хронічна непередбачувана стресогенна стимуляція або поведінкова ізоляція щурів із діабетом істотно збільшують прояви депресії та забезпечують стабільне формування адекватної діабет-залежної моделі депресії в експериментах на тваринах. Утримання щурів у ізоляції (підгрупа DmD2) виглядає більш придатним для емпіричних досліджень, оскільки смертність тварин у даній підгрупі була нижчою.

\section{REFERENCES}

1. A. Engum, A. Mykletun, K. Midthjell, et al., "Depression and diabetes: a large population-based study of sociodemographic, lifestyle, and clinical factors associated with depression in type 1 and type 2 diabetes," Diab. Care, 28, 1904-1909 (2005).

2. P. J. Goodnick, J. H. Henry, and V. M. Buki, "Treatment of depression in patients with diabetes mellitus," J. Clin. Psychiat., 56, 128-136 (1995).

3. R. R. Rubin, P. Ciechanowski, L. E. Egede, et al., "Recognizing and treating depression in patients with diabetes," Curr. Diab. Rep., 4, 119-125 (2004).

4. J. A. Gavard, P. J. Lustman, and R. E. Clouse, "Prevalence of depression in adults with diabetes. An epidemiological evaluation," Diab. Care, 16, 1167-1178 (1993).

5. P. J. Lustman, L. S. Griffith, R. E. Clouse, et al., "Psychiatricillness in diabetes-mellitus-relationship to symptoms and glucose control," J. Nerv. Ment. Dis., 174, 736-742 (1986).

6. P. J. Lustman, R. J. Anderson, K. E. Freedland, et al., "Depression and poor glycemic control - A meta-analytic review of the literature," Diab. Care, 23, 934-942 (2000).

7. G. R. Heninger and D. S. Charney, "Monoamine receptor systems and anxiety disorders," Psychiat. Clin. North Am., 11, 309-326 (1988).

8. D. Hu, H. Gu, Y. Xiong, et al., "Changes and significance of orphanin FQ and monoamine neurotransmitters in patients with postpartum depression," Chin. J. Nerv. Ment. Dis., 29, 321-322 (2003)

9. S. Miyata, S. Hirano, and J. Kamei, "Diabetes attenuates the antidepressant-like effect mediated by the activation of 5-HT1A receptor in the mouse tail suspension test," Neuropsychopharma, 29, 461-469 (2004).

10. J. L. Scholl, K. J. Renner, G. L. Forster, et al., "Central monoamine levels differ between rat strains used in studies of depressive behavior," Brain Res., 1355, 41-51 (2010).

11. P. A. Jimenez Vasquez, P. Salmi, S. Ahlenius, et al., "Neuropeptide $\mathrm{Y}$ in brains of the flinders sensitive line rat, a model of depression. Effects of electroconvulsive stimuli and d-amphetamine on peptide concentrations and locomotion," Behav. Brain Res., 111, 115-123 (2000).

12. K. A. Paschos, S. Veletza, and E. Chatzaki, "Neuropeptide and sigma receptors as novel therapeutic targets for the pharmacotherapy of depression," CNS Drugs, 23, 755-772 (2009)

13. S. Ferraro, P. Perrone-Filardi, G. Maddalena, et al., "Comparison of left ventricular function in insulin- and noninsulin-dependent diabetes mellitus," Am. J. Cardiol., 71, 409414 (1993).

14. S. Ferraro, S. Fazio, M. Santomauro, et al., "Cardiac function and sympathetic activity in young diabetics," Diab. Res. Clin. Pract., 8, 91-99 (1990).

15. H. Djursing, H. C. Nyholm, C. Hagen, et al., "Clinical and hormonal characteristics in women with anovulation and insulin-treated diabetes mellitus," Am. J. Obstet. Gynecol., 143, 876-882 (1982).

16. R. Rosmond, "Stress induced disturbances of the HPA axis: a pathway to type 2 diabetes?" Med. Sci. Monit., 9, RA35-39 (2003).

17. S. M. Villafuerte, "Molecular genetics of affective disorders: positional cloning and gene-based association approaches," $D A I-B, \mathbf{6 3}, 1152$ (2002).

18. H. Kim, W. W. Whang, H. T. Kim, et al., "Expression of neuropeptide $\mathrm{Y}$ and cholecystokinin in the rat brain by chronic mild stress," Brain Res., 983, 201-208 (2003).

19. N. Zarjevski, I. Cusin, R. Vettor, et al., "Chronic intracerebroventricular neuropeptide- $\mathrm{Y}$ administration to normal rats mimics hormonal and metabolic changes of obesity," Endocrinology, 133, 1753-1758 (1993). 